\title{
PENGENDALIAN SUMBERDAYA IKAN DI ESTUARIA SUNGAI MUSI
}

\author{
Eko Prianto' ${ }^{1)}$, Siswanta Kaban ${ }^{2)}$, Solekha Aprianti'i), dan Romie Jhonnerie ${ }^{3)}$ \\ 1) Peneliti pada Pusat Penelitian Pengelolaan Perikanan dan Konservasi Sumberdaya Ikan \\ 2) Peneliti pada Balai Riset Perikanan Perairan Umum \\ 3) Dosen pada Fakultas Perikanan dan IImu Kelautan Universitas Riau \\ Teregristrasi I tanggal: 9 April 2010; Diterima setelah perbaikan tanggal: 20 April 2010; \\ Disetujui terbit tanggal: 30 April 2010
}

\begin{abstract}
ABSTRAK
Perairan estuaria Sungai Musi merupakan daerah penangkapan ikan yang potensial di Provinsi Sumatera Selatan, sehingga di wilayah ini terjadi aktifitas penangkapan yang cukup padat. Akibatnya terjadi tekanan yang cukup besar terhadap sumberdaya ikan di kawasan ini. Fungsi ekologi estuaria sebagai spawning ground dan nursery ground mulai mengalami gangguan akibat intensitas penangkapan yang besar. Beberapa alat tangkap ikan yang tidak selektif beroperasi dalam jumlah banyak sehingga menyebabkan penurunan terhadap stok ikan. Akibatnya konflik pemanfaatan ruang sering terjadi antar sesama nelayan atau pengguna lainnya. Seperti konflik jaring trawl dengan gill net dan pancing rawai dan konflik nelayan tuguk dengan pengemudi kapal. Untuk menyelesaikan konflik di atas dan menjaga kelestarian sumberdaya ikan di estuaria Sungai Musi, beberapa langkah pengendalian yang direkomendasikan adalah melakukan pengaturan penangkapan ikan, melakukan sosialisasi peraturan perikanan kepada masyarakat, meningkatkan kapasitas kelembagaan pengelolaan perikanan, pelarangan penggunaan alat tangkap tertentu, dan memberikan bantuan modal usaha kepada nelayan.
\end{abstract}

KATAKUNCl: $\quad$ estuaria Sungai Musi, pengendalian, sumberdaya ikan

ABSTRACT: $\quad$ Resources controlling of fish in Musi River estuary. By: Eko Prianto, Siswanta Kaban, Solekha Aprianti, and Romie Jhonnerie

Estuary of Musi River is a potential fishing areas in South Sumatra Province, so that in this region occur fairly heavy fishing activity. The consequence is a large pressure on fish resources of this region. The ecological functions of estuaries as nursery ground and spawning ground, begin to experience problems due to the large fishing intensity. Some fishing gear that does not selectively operate in large quantities resulted in a decline of fish stocks. As the result spatial use conflicts often occur between fishermen or other user, as examples is the conflict between trawl fishing with gill nets and longline operator and the operator of driver tuguk ship. To resolve the above conflict and preserve the fish resources in the estuary of the River Musi, a few recomendation that must be addressed several step must doing fisheries regulations to disseminate to the public, enhance institutional capacity for fisheries management, ban the use of certain fishing gear and provide venture capital assistance to fishermen.

\section{KEYWORD : $\quad$ Musi River estuary,controllingt, fish resources}




\section{Pendahuluan}

Jenis-jenis ikan yang banyak terdapat di wilayah estuaria antara lain ikan, udang dan moluska. Jenis ikan, udang dan moluska yang terdapat di perairan estuaria meliputi ikan bawal putih (Pampus argenteus), bawal hitam (Formio niger), bilis (Stolephorus indicus), manyung (Arius thalassinus), kurau (Eleutheronema tetradactylum), tenggiri (Scomberomorus guttatus), kakap putih (Lates Calcalifer), udang (Penaeus sp.), cumi-cumi (Loligo sp.), kepiting bakau (Scylla spp.), rajungan (Portunus pelagicus), kerang, dan siput.

Estuaria Sungai Musi memiliki luas sebesar $\pm 736 \mathrm{~km}^{2}$ (Direktorat Jenderal Pesisir dan Pulau-Pulau Kecil, 2001) dan diperkirakan memiliki panjang hingga $50 \mathrm{~km}$ (hingga Desa Upang) dari tepi pantai. Gaffar et al. (2006) menyatakan di perairan estuaria Kabupaten Banyuasin tahun 2006 telah didapatkan 107 jenis ikan dan udang, dengan sebaran di perairan estuaria Upang dan Sungsang terdapat 59 jenis, estuaria Sembilang 51 jenis dan estuaria Banyuasin 63 jenis. Semua jenis ikan dan udang tersebut ditangkap dengan menggunakan berbagai macam alat tangkap seperti pancing, rawai, jaring tangsi, belad, dan sebagainya. Namun secara umum jenis biota yang mendiami wilayah ini terdiri atas jenis moluska, krustacea, ikan, dan bentos yang terdapat di dasar perairan dengan jumlah jenis yang sedikit.

Ekosistem estuaria Sungai Musi memiliki peran yang sangat besar dalam mendukung kehidupan masyarakat di Sumatera Selatan. Setiap tahun wilayah muara ini menghasilkan lebih dari 3.000 ton ikan yang berfungsi sebagai sumber pangan bagi masyarakat luas (Dinas Perikanan
Sumatera Selatan, 2007). Wilayah muara mempunyai fungsi ekologi sebagai daerah asuhan (nursery ground) dan tempat mencari makan (feeding ground) bagi berbagai jenis ikan dan udang. Pada tahun 2006 hasil tangkapan ikan di Kabupaten Banyuasin sebesar 7.448,6 ton yang sebagian besar ditangkap di wilayah muara (Dinas Perikanan Sumatera Selatan, 2007).

Pada tahun 2006 di Kabupaten Banyuasin terjadi penurunan hasil tangkapan yang berasal dari perairan umum dari 7.535,4 ton pada tahun 2005 menjadi $7.448,6$ ton pada tahun 2006 (Dinas Perikanan Sumatera Selatan, 2007). Penurunan hasil tangkapan nelayan di perairan umum juga dialami oleh kabupaten lainnya di Sumatera Selatan dengan kisaran 1-3 \%.

Menurut Septifitri (2003) penyebab menurunnya sumberdaya ikan di estuaria Sungai Musi karena kelebihan tangkapan dan penggunaan alat tangkap yang tidak ramah lingkungan seperti trawl, tuguk, dan belad. Penggunaan trawl secara illegal sangat marak dilakukan nelayan di Sumatera Selatan. Penggunaan trawl ini tidak memiliki izin dari pemerintah daerah setempat dan sebagian besar nelayan di kawasan ini menggunaan trawl. Penggunaan trawl ini terus dilakukan hingga saat ini. Pengoperasian trawl saat ini telah menimbulkan berbagai persoalan baru seperti rusaknya jaring hanyut akibat tertabrak trawl atau menurunnya hasil tangkapan akibat operasi trawl.

Penelitian ini bertujuan untuk memecahkan permasalahan yang dihadapi masyarakat dalam pemanfaatan sumberdaya ikan di estuaria Sungai Musi. 


\section{Keadaan Umum Sumberdaya Perikanan}

\section{Sumberdaya Ikan}

Hasil penelitian pada tahun 2008 menunjukan jenis ikan di estuaria Sungai Musi Sumatera Selatan dijumpai sebanyak 95 jenis (Suman et al., 2008). Jenis ikan yang banyak tertangkap sebagian besar merupakan ikan laut dan hanya sebagian kecil ikan air tawar. Hasil analisis besaran stok biomas ikan di kawasan estuaria Sungai Musi diperoleh nilai $24-105 \mathrm{~kg} / \mathrm{km}^{2}$.
(Gambar 1). Hasil dari pengamatan di lapangan dari 96 jenis ikan yang tertangkap, jenis ikan air tawar yang tertangkap hanya empat jenis diantaranya ikan juaro (Pangasius polyuranodon), seluang (Rasbora argyrotaenia), sepengkah (Parambassis sp.), dan udang galah (Macrobrachium rosenbergii), sedangkan sisanya merupakan ikan laut sebanyak 92 jenis (Suman et al., 2008). Menurut Prianto \& Suryati (2010) bahwa potensi sumberdaya ikan di muara Sungai Musi pada tahun 2008 mencapai sebesar $\pm 18.000-77.600 \mathrm{~kg} /$ tahun.

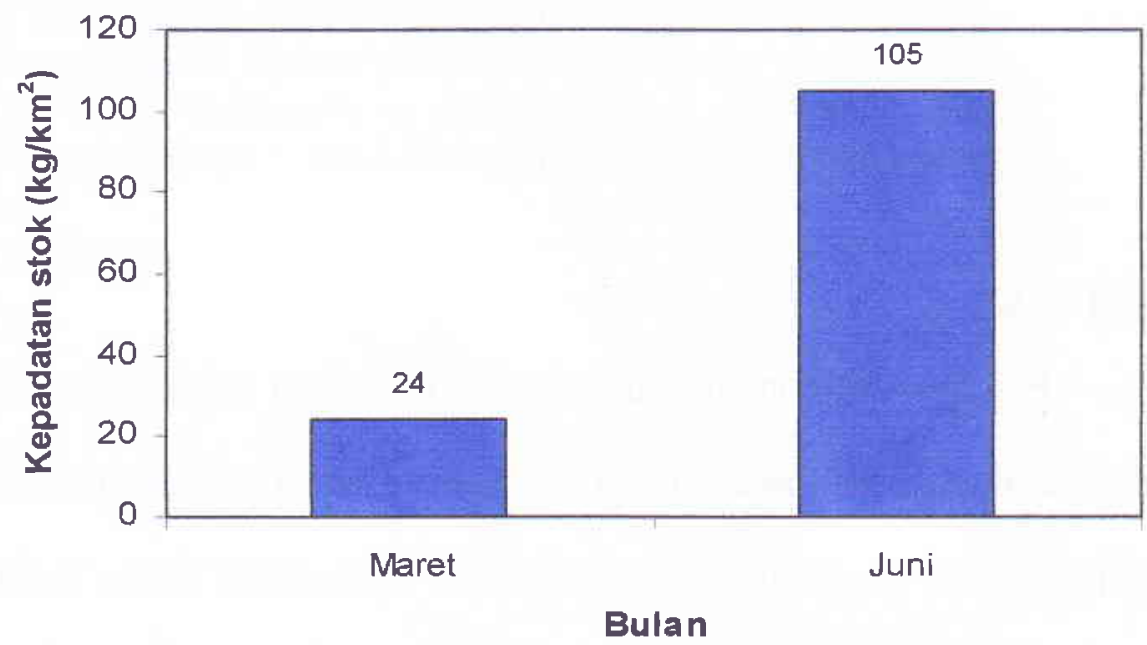

Gambar 1. Kepadatan stok ikan estuaria Sungai Musi pada tahun 2008. Figure 1. Fish stock density of Musi River estuary in 2008.

Dari hasil penelitian yang dilakukan Gaffar et al. (2006) di estuary Sumatera Selatan diperoleh nilai catch per unit of effort berbagai alat tangkap. Hasil tangkapan dengan menggunakan jaring kantong di daerah perairan estuaria Sumatera Selatan mempunyai nilai CPUE berkisar antara 2,6-3,12 kg/jam. Alat tangkap belad berkisar 0,31-0,89 kg/jam dan jaring tangsi terdapat di perairan Sungsang yaitu $2-3,83 \mathrm{~kg} / \mathrm{jam}$. Untuk alat tangkap tuguk tancap memiliki nilai CPUE sekitar 0,51 kg/jam (Gambar 2). 


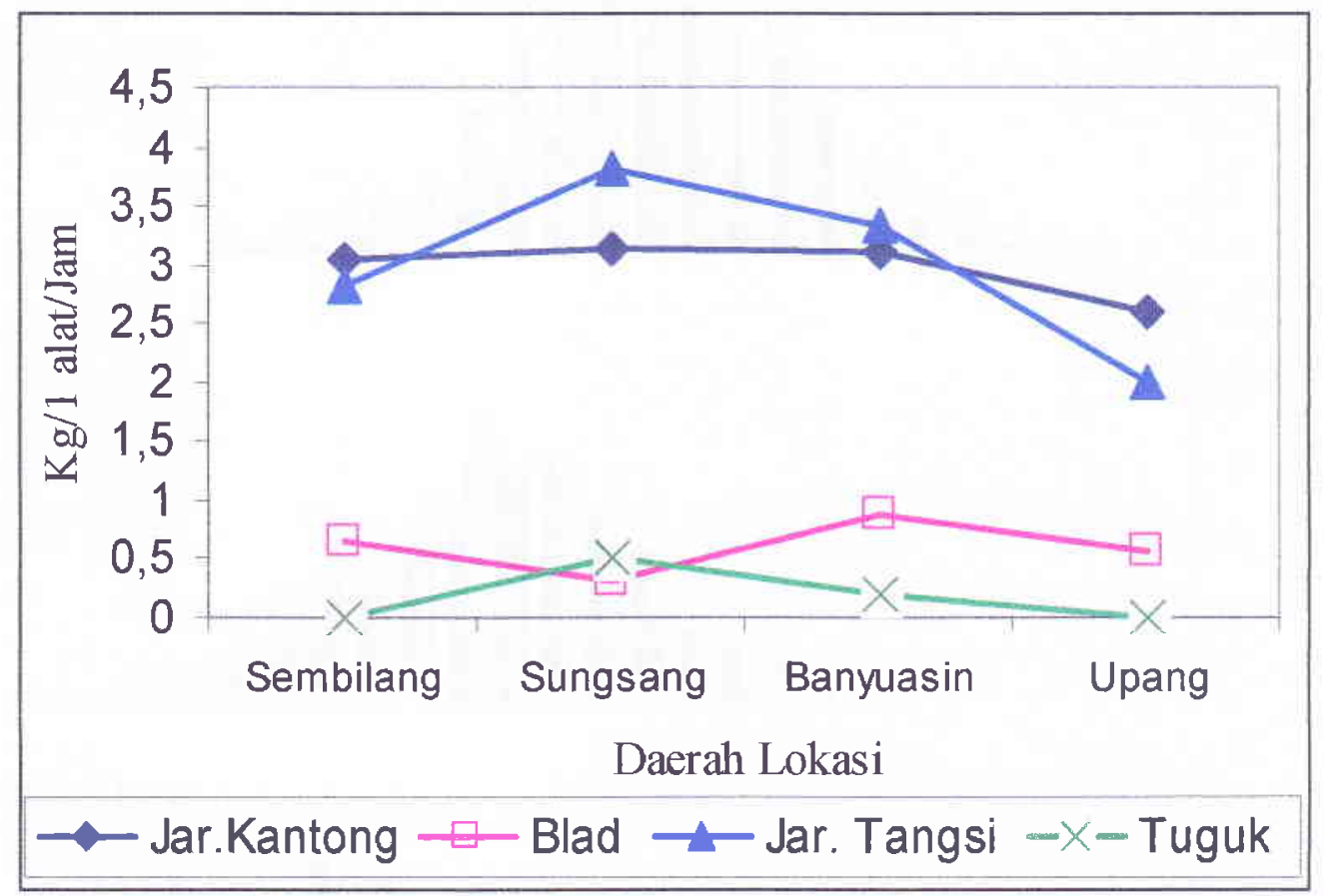

Gambar 2. Hasil tangkapan per per satuan upaya untuk setiap jenis alat tangkap diperairan estuaria Kabupaten Banyuasin tahun 2006.

Figure 2. Catches per unit effort according to gear type in Banyuasin estuary in 2006.

Sumber/Sources: Gaffar et al. (2006)

\section{Alat Tangkap}

\section{Struktur dan Spesifikasi Alat Tangkap}

Aktvitas penangkapan di estuaria Sungai Musi dilakukan hampir sepanjang tahun, namun alat tangkap yang digunakan ada yang bersifat musiman dan ada yang sepanjang tahun. Gaffar et al., (2006) menyatakan bahwa jumlah jenis alat tangkap yang beroperasi di estuaria yang bermuara di Selat Bangka sebanyak 14 jenis yaitu pancing gulung, rawai, jaring tangsi hanyut, jaring kantong, jaring cawang, belad, tuguk tancap, tuguk kumbang, tuguk apung, sondong, jala udang, sondong udang, sesar udang, dan bubu kepiting. Hasil pengamatan tahun 2010 jumlah jenis alat tangkap di etuaria Sungai Musi sebanyak 13 jenis yaitu pancing gulung, rawai, jaring tangsi hanyut, jaring kantong, traw/ dorek, jaring cawang, belad, tuguk tancap, tuguk apung, jala udang, sondong udang, bagan tancap, dan bubu kepiting. Namun alat tangkap yang beroperasi sepanjang tahun hanya lima jenis yaitu pancing gulung, rawai, jaring tangsi hanyut, trawl dorek, dan jaring cawang sedangkan lainnya bersifat musiman. Jumlah alat tangkap di estuaria Sungai Sembilang (termasuk estuaria Sungai Musi) disajikan pada Gambar 3 di bawah. 


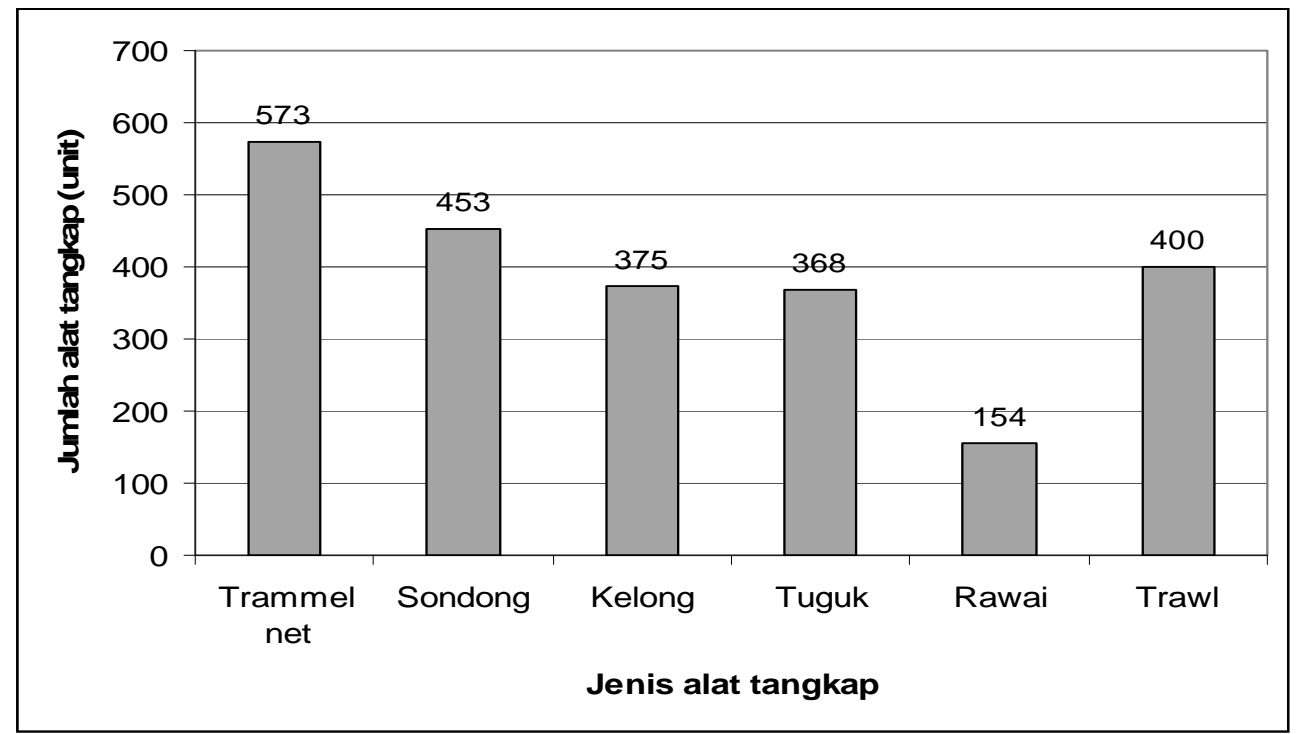

Gambar 3. Jumlah alat tangkap di estuaria Sungai Sembilang.

Figure 3. Amount of fishing gear in Sungai Sembilang estuary. Sumber/Sources : Septifitri (2003)

Pengoperasian alat tangkap tergantung musim penangkapan, musim penangkapan berlangsung pada bulan Juni sampai September untuk komoditas udang dan rajungan, sedangkan untuk kepiting bakau musim penangkapan berlangsung pada bulan Nopember sampai Januari. Semua jenis ikan dapat ditangkap sepanjang tahun terutama ikan gulamo, belanak, bawal putih, kiper, bulu ayam, dan sembilang. Alat tangkap yang digunakan nelayan ada yang bersifat selektif dan tidak selektif terhadap jenis ikan yang ditangkap. Selektivitas beberapa alat tangkap di estuaria Sungai Musi dapat dilihat pada Lampiran 1.

\section{Konflik Kepentingan Antar Alat Tangkap}

Alat tangkap yang terdapat di estuaria Sungai Musi dapat dikelompokkan menjadi dua yaitu bersifat statis dan dinamis. Alat tangkap yang bersifat statis diantaranya pancing gulung, rawai, jaring tangsi hanyut, jaring kantong, jaring cawang, belad, tuguk tancap, tuguk apung, bagan tancap, dan bubu kepiting, alat tangkap yang bersifat dinamis antara lain, trawl dorek, jala udang, dan sondong udang. Alat tangkap ini penyebarannya tidak merata, tergantung dengan lokasi yang cocok dalam penggunaannya. Contohnya belad digunakan di tepi perairan, tuguk di tengah perairan dan trawl digunakan di tengah perairan dengan cara ditarik dengan kapal.

Interaksi antar alat tangkap di estuaria Sungai Musi saling tumpang-tindih karena tidak ada aturan penangkapan. Dalam suatu kawasan perairan penggunaan alat tangkap lebih dari satu jenis dan dalam pengoperasianya seringkali terjadinya tumpang-tindih. Hal ini dapat dilihat pada pengoperasial trawlyang sering berbenturan dengan alat tangkap bagan, rawai, dan jaring. Alat tangkap yang terkena trawl akan rusak dan banyak yang tidak dapat digunakan lagi. Pengaturan pengoperasian alat tangkap sampai saat ini belum diatur 


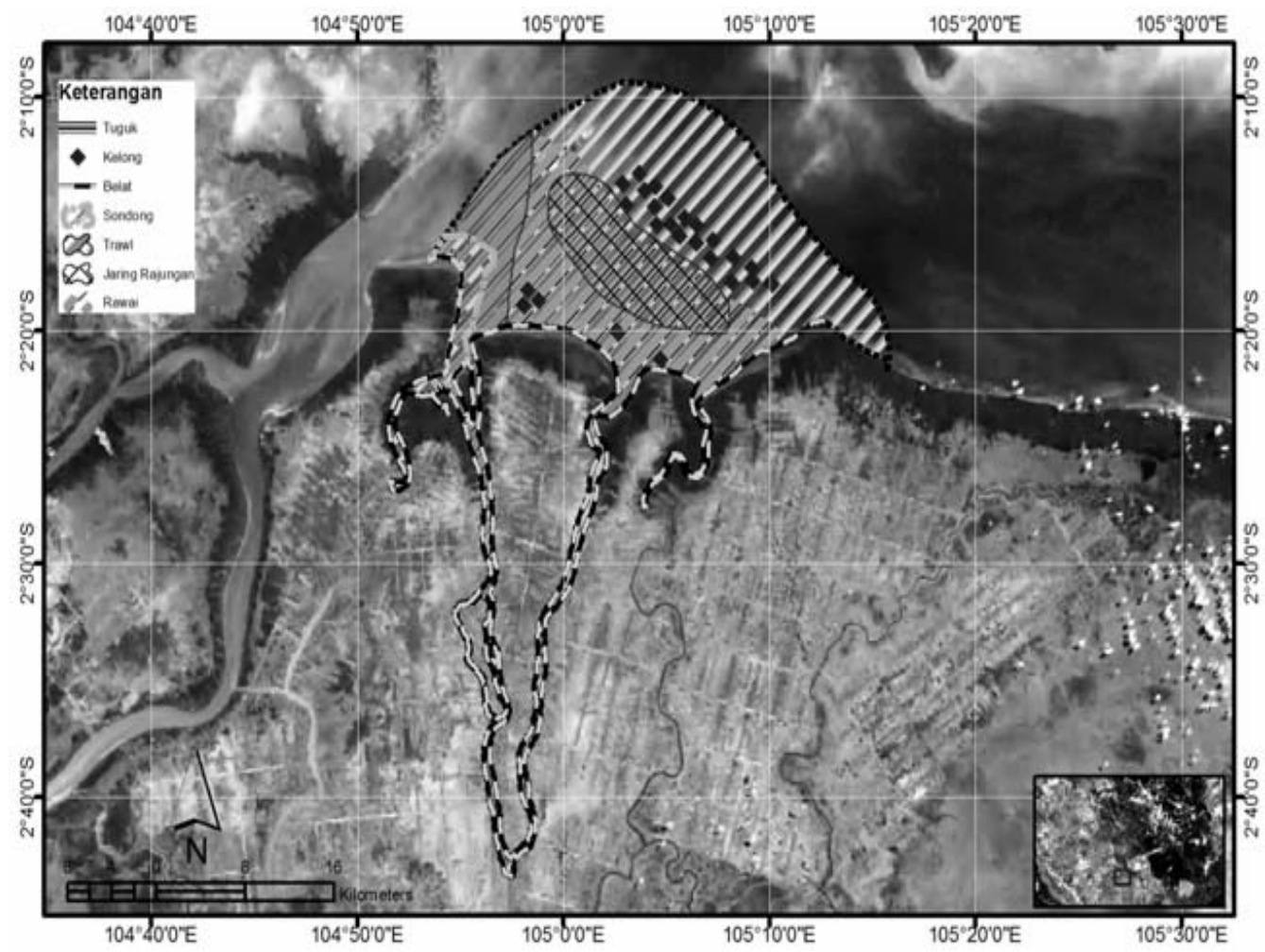

Gambar 4. Penyebaran alat tangkap di estuaria Sungai Musi. Figure 4. Distribution of fishing gears in Musi River estuary.

di kawasan estuaria Sungai Musi. Penyebaran alat tangkap dapat dilihat pada Gambar 4 di bawah.

\section{Kondisi Sosial-Ekonomi Masyarakat Nelayan}

Kecamatan Banyuasin II merupakan salah satu kecamatan yang berada di wilayah Kabupaten Banyuasin dengan luas wilayah $\pm 369.667,5$ ha terdiri atas 21 desa. Di sebelah utara kecamatan ini berbatasan dengan Provinsi Jambi, sebelah selatan dengan Kecamatan Makarti Jaya dan Kecamatan Muara Telang, di sebelah barat dengan Kecamatan Lalan dan Kabupaten Musi Banyuasin dan sebelah timur dengan Selat Bangka (Provinsi Bangka Belitung). Ibu kota kecamatan ini adalah Sungsang dengan jarak ke pusat pemerintahan Kabupaten Banyuasin (Pangkalan Balai) sekitar $115 \mathrm{~km}$ dan kota Palembang sekitar 73 km (Kecamatan Banyuasin II, 2010).

Masyarakat di Kecamatan Banyuasin II berprofesi sebagai nelayan, dan sebagian kecil berprofesi sebagai pedagang, pegawai negeri, petani, dan sebagainya. Wardoyo et al., (2001) menyatakan bahwa 90\% penduduk yang tinggal di perairan estuaria Banyuasin bekerja sebagai nelayan atau pengolah produk perikanan.

Kecamatan Sungsang merupakan pemukiman yang sangat padat dengan jumlah penduduk sebesar 46.575 jiwa. Pemukiman yang dibangun masyarakat terletak di sepanjang pantai (muara sungai) dengan bentuk rumah panggung yang 
terbuat dari kayu dan hanya sebagian kecil yang terbuat dari semen. Walaupun merupakan perkampungan yang didominansi dengan rumah panggung, namun jalan utama dapat dilalui kendaraan bermotor dan becak.

Masyarakat yang tinggal disini terdiri atas multi etnis yaitu Palembang, Jawa, Cina, dan Bugis. Masyarakat yang tinggal di Kecamatan Banyuasin II hidup rukun walaupun hidup dalam keberagaman. Topografi wilayah ini terdiri atas rawa-rawa dengan ketinggian kurang dari $50 \mathrm{~m}$, sehingga daerah ini sangat dipengaruhi oleh pasang surut air laut. Jenis tanahnya adalah hidromorf aluvial dengan bahan induk endapan triat (marin). Tipe iklim berdasarkan atas klasifikasi Schmith dan Fergusson termasuk iklim tropis tipe A.

Sesuai dengan letaknya di wilayah pesisir, maka nelayan adalah profesi yang paling utama kehidupan masyarakat di Kecamatan Banyuasin II. Alat tangkap yang digunakan beranekaragam mulai statis hingga dinamis dan mulai tradisional hingga yang modern. Alat tangkap yang sering digunakan adalah jaring, tuguk, bagan, trawl, rawai, sondong, belad, dan bubu. Alat tangkap inilah yang menangkap berbagai jenis ikan mulai yang berukuran kecil hingga besar, mulai ekonomis rendah hingga tinggi. Profesi menangkap ikan ini telah menjadi urat nadi bagi pertumbuhan perekonomian bagi ribuan masyarakat pesisir di Sumatera Selatan. Sehingga Sungsang dikenal sebagai daerah penghasil ikan terbesar di Sumatera Selatan.

\section{Kearifan Lokal Dalam Hal Pengendalian Pemanfaatan Sumberdaya}

Sumberdaya pesisir bersifat common acess (milik umum) sehingga semua orang dapat mengelola dan memanfaatkan sumberdaya tersebut tanpa larangan. Namun pemanfaatan sumberdaya ikan ini terbentur dengan aturan pemerintah daerah berupa sistem "lelang". Aturan lelang ini hanya berlaku untuk kawasan di tepi sungai atau laut dengan luas tertentu. Tetapi untuk di badan sungai atau tengah perairan aturan ini tidak berlaku. Lelang ini berarti setiap tahunnya masyarakat (orang/kelompok) membayar sejumlah uang untuk kawasan yang dikelolanya. Setiap tahun pemenang lelang dapat orang yang berbeda-beda. Jika suatu kawasan telah dimenangkan oleh seseorang maka orang lain tidak boleh melakukan penangkapan didaerah tersebut.

Untuk kawasan ditengah perairan maka aturan penangkapan belum pernah di buat atau diatur oleh masyarakat dan pemerintah daerah. Masyarakat melakukan penangkapan sesuai dengan keinginannya tergantung penyebaran ikan. Akibatnya dalam suatu kawasan dapat ditemukan berbagai macam alat tangkap yang jaraknyapun sangat berdekatan. Sehingga tidak jarang alat tangkap yang bersifat merusak seperti trawl dan sondong merusak alat tangkap jaring atau rawai. Permasalahan ini sampai saat ini sering terjadi di kawasan estuaria Sungai Musi.

\section{PENGENDALIAN SUMBERDAYA IKAN}

Konflik yang terjadi di Sungai Sembilang (termasuk estuaria Sungai Musi) telah terjadi antara alat tangkap menetap tuguk dengan alat tangkap bergerak yaitu sondong dan trawl. Alat tangkap menetap merasa hasil tangkapannya menurun semenjak terjadinya lonjakan jumlah trawl dan sondong yang beroperasi. Demikian juga terjadi konflik antara pengoperasian trammel net dan pancing rawai berhadapan dengan trawl dan sondong. Alat tangkap trawl dan sondong sering menyeret atau menabrak sampai putus jaring trammel net dan pancing rawai. Konflik pemanfaatan juga 
terjadi antara kapal-kapal ikan lokal dengan kapal ikan dari daerah lain seperti dari Jambi, Riau, Jakarta, Jawa Tengah, dan Thailand. Kapal-kapal dari daerah lain umumnya menggunakan jaring trawl yang lebih besar, sehingga nelayan lokal merasa kalah bersaing dalam menangkap udang atau ikan. Konflik tersebut sudah sering berujung pembakaran kapal trawl dari daerah lain oleh nelayan lokal (Septifitri, 2003). Untuk mengatasi hal ini ada beberapa langkah pengendalian yang direkomendasikan diantaranya :

\section{Pengaturan penangkapan}

Estuaria merupakan ekosistem yang subur berfungsi sebagai daerah pengasuhan (nursery ground) dan pemijahan (feeding ground). Sebenarnya fungsi inilah yang paling menonjol, namun karena keterbatasan pengetahuan dan alat tangkap justeru fokus penangkapan masyarakat beralih ke wilayah ini. Akibatnya hasil tangkapan ikan yang berukuran juvenil lebih banyak tertangkap daripada yang berukuran besar. Kalaupun ukuran besar yang tertangkap tidak jarang rata-rata sudah mencapai matang gonad seperti ikan sembilang (Plotasus canius), duri kawat (Osteogeneiosus militaris) yang setiap bulannya memiliki tingkat kematangan gonad (TKG) I-IV (Gaffar et al., 2007). Jika kondisi ini berlanjut kedepannya stok sumberdaya ikan di estuaria Sungai Musi akan mengalami penurunan tajam.

Untuk mengantisipasi hal tersebut diperlukan pengaturan penangkapan yang meliputi waktu penangkapan, alat tangkap yang boleh beroperasi dan pembatasan jumlah alat tangkapan. Pengaturan penangkapan ini diperlukan mengingat jumlah nelayan yang terus meningkat dan alat tangkap yang beroperasi tidak ramah lingkungan. Selanjutnya dibuat zonasi penangkapan agar tempat-tempat tertentu yang berfungsi sebagai pemijahan dan asuhan tidak rusak akibat aktivitas penangkapan.

Pengaturan penangkapan ini juga ditujukan agar lalu lintas pelayaran menjadi lancar. Karena setiap hari penangkapan dilakukan di alur lintas pelayaran kapalkapal tanker dan penumpang. Akibatnya banyak jaring nelayan yang rusak bahkan tidak jarang yang bertabrakan dengan kapal-kapal tanker tersebut. Beberapa alat tangkap seperti tuguk juga sering dipasang melintang hingga ketengah sungai, ini jelas akan mengurangi ruang untuk alur kapal. Hal-hal seperti ini perlu diatur guna mencegah konflik dan kerugian materi lainnya.

\section{Melakukan sosialisasi peraturan perikanan}

Beberapa peraturan perikanan telah banyak dibuat di Indonesia, namun sosialisinya belum mencapai masyarakat bawah. Ditambah lagi tingkat pendidikan masyarakat nelayan sangat rendah bahkan ada yang tidak bisa membaca. Sebagai contoh banyak nelayan yang tidak mengetahui bahwa setiap alat tangkap dan kapal penangkapan yang digunakan memiliki izin dari instansi terkait. Kemudian sebenarnya alat tangkap trawl sudah dilarang digunakan beroperasi di Indonesia kecuali di beberapa tempat yang diizinkan. Pelarangan penggunaan alat tangkap trawl berdasarkan atas Keppres RI No. 39 Tahun 1980 tentang larangan penggunaan pukat harimau atau trawl di perairan Indonesia (http://www.ejfoundation.org/pdf/ JALAstoptrawlbahasa.pdf). Kenyataan sampai saat ini banyak kita temui trawl yang beroperasi di Sumatera Selatan. Untuk itu 
perlu dilakukan penyadaran kepada masyarakat tentang bahaya penggunaan trawl terhadap ekosistem perairan.

\section{Meningkatkan kelembagaan kelompok nelayan}

Kelembagaan kelompok nelayan sangat diperlukan bagi masyarakat sebagai wadah dalam menyampaikan aspirasi kepada pemerintah. Kapasitas kelembagaan yang telah terbentuk sebaiknya perlu diperkuat kembali sehingga masyarakat mampu mencari jalan keluar dari masalah yang dihadapinya. Kelompok nelayan yang telah ada perlu dilakukan pembinaan melalui berbagai pelatihan. Pelatihan yang cocok diberikan berupa pelatihan administrasi, pengembangan diri, pengolahan ikan, dan pengelolaan lingkungan laut dan sungai. Dampak yang diperoleh dari kegiatan ini diantarnya meningkatkan taraf hidup masyarakat.

\section{Pelarangan penggunaan alat tangkap tertentu}

Di perairan estuaria Sungai Musi, terdapat empat jenis alat yang berpotensi menimbulkan konflik, yaitu trawl, sondong, tuguk, dan belad. Karena alat ini non selektif, maka komoditi sampingannya adalah sebagian besar ikan-ikan yang berukuran juvenil (anak-anak atau larva ikan dan udang). Bila keadaan demikian terus berlangsung maka akan terjadi penurunan potensi sumberdaya ikan dan udang secara keseluruhan.

Dalam pengoperasiannya keempat jenis alat tangkap ini juga menimbulkan konflik misalnya jarak antara satu bagan dengan bagan yang lain juga terlalu sering menimbulkan konflik. Demikian pula tumpang-tindih ruang operasi antara sondong dan trawl yang alatnya ditarik, dengan gill net dan pancing rawai alatnya dipasang/dibentang dalam air. Sering terjadi tabrakan fisik antar alat sewaktu operasi yang menimbulkan perkelahian. Pengalokasian dan penataan pemanfaatan belum terpola dengan baik. Pengalokasian alat tangkap yang memanfaatkan sumberdaya ikan dilakukan berdasarkan atas hasil kajian kondisi lingkungan dan kajian tingkat pemanfaatan yang telah dicapai sebelumnya. Alokasi pemanfaatan harus dapat menjawab penataan pemanfaatan yang mengatur secara berimbang jumlah alat, ukuran alat, waktu penangkapan, areal masing-masing alat tangkap atau jalur-jalur penangkapan dari masing-masing alat tangkap.

\section{Memberikan bantuan modal usaha kepada nelayan}

Usaha penangkapan tidak dapat lepas dari "sistem ijon atau tengkulak" di mana masyarakat menjual hasilnya kepada orang tertentu. Karena keterbatasan modal nelayan melakukan peminjaman kepada orang tertentu dengan bunga yang besar dan menjual hasil tangkapan dengan harga yang murah. Kondisi ini menyebabkan masyarakat nelayan di estuaria Sungai Musi yang hidup dalam kondisi miskin. Untuk melepaskan diri dari belenggu kemiskinan ini diperlukan upaya pemerintah dalam memberikan pinjaman lunak dan jangka panjang sehingga masyarakat dapat terlepas dari sistem ijon atau tengkulak.

\section{Kesimpulan dan Rekomendasi}

\section{Kesimpulan}

1. Sumberdaya ikan di estuaria Sungai Musi memiliki potensi yang cukup besar sebagai stok benih ikan untuk perairan laut, sehingga pemanfaatannya dilakukan secara hati-hati.

2. Konflik horisontal yang terjadi diakibatkan karena pemanfaatan ruang 
(daerah penangkapan) yang terbatas sehingga penggunaan alat tangkap sering terjadi tumpang-tindih.

3. Pengelolaan sumberdaya ikan di estuaria Sungai Musi belum dilakukan dengan baik, karena belum dilakukan pengaturan terhadap jenis alat tangkap yang boleh beroperasi, jumlah alat, areal atau jalur-jalur alat tangkap yang beroperasi dan ukuran mata jaring.

\section{Rekomendasi}

Pemerintah daerah perlu membuat peraturan daerah mengenai pengelolaan sumberdaya ikan di estuaria Sungai Musi agar tumpang-tindih penangkapan, kerusakan dan over exploitasi dapat dihindari sehingga kelestarian sumberdaya ikan dapat dipertahankan.

\section{DAFTAR PUSTAKA}

Direktorat Jenderal Pesisir dan Pulau-Pulau Kecil. 2001. Pengelolaan Lingkungan Kawasan Pesisir Estuaria di Sungai Musi, Sumatera Selatan. Jakarta.

Dinas Perikanan Sumatera Selatan. 2007. Statistika Perikanan Provinsi Sumatera Selatan. Palembang.

Gaffar, A. K., Rupawan, K. Fattah, M. Jahri, \& B. Waro. 2006. Riset perikanan tangkap di perairan estuaria yang bermuara di Selat Bangka. Laporan Teknis. Balai Riset Perikanan Perairan Umum. Pusat Riset Perikanan Tangkap. Departemen Kelautan dan Perikanan. 34 pp. http://www.ejfoundation.org/pdf/ JALAstoptrawlbahasa.pdf. Ketika Perikanan Menjadi Sesuatu yang Mematikan: Dampak Lingkungan dan Sosial Trawl di Sumatera Utara. 8 pp.

Gaffar, A. K., Rupawan, K. Fattah, M. Jahri, \& B. Waro. 2007. Riset pola pengelolaan sumber daya perikanan di daerah estuari Sungai Musi Sumatera Selatan. Laporan Teknis. Balai Riset Perikanan Perairan Umum. Pusat Riset Perikanan Tangkap. Departemen Kelautan dan Perikanan. 36 pp.

Prianto, E. \& N. K. Suryati. 2010. Komposisi jenis dan potensi sumber daya ikan di muara Sungai Musi. Jurnal Penelitian Perikanan Indonesia. Pusat Riset Perikanan Tangkap. 16 (1): 1-8.

Suman, A., Husnah, E. Prianto, \& N. K. Suryati. 2008. Strategi pengelolaan perikanan estuari Sungai Musi. Laparan Teknis. Balai Riset Perikanan Perairan Umum.

Septifitri. 2003. Pengelolaan sumber daya udang di estuaria Sungai Sembilang. Makalah Pengantar Falsafah Sains. http://rudyct.com/PPS702-ipb/07134/ septifitri.pdf.

Wardoyo, S. A. 2001. Laporan survei perikanan di kawasan CTN Sembilang, bulan Juli 2001. Proyek Konservasi Lahan Basah Pesisir Berbak-Sembilang GEF MSP (TF-0240011). Wetland International Asia Pasipic Indonesia Program. 
Pengendalian Sumber Daya Ikan di Estuaria Sungai Musi (Prianto, E., et al.)

Lampiran 1. Bahan, spesifikasi, cara operasi, dan selektivitas alat tangkap beberapa alat tangkap di estuaria Sungai Musi

Appendix 1. Material, specification, operation way, and fishing gear selectivity of several fishing gear in Musi River estuary

\begin{tabular}{|c|c|c|c|}
\hline No. & $\begin{array}{l}\text { Nama setempat/ } \\
\text { Local Name }\end{array}$ & $\begin{array}{c}\text { Bahan atau alat, spesifikasi, dan ukuran/ } \\
\text { Materials or equipment, specifications, and size }\end{array}$ & $\begin{array}{l}\text { Operasional alat/ } \\
\text { Operational tools }\end{array}$ \\
\hline 1. & Pancing gulung & $\begin{array}{l}\text { Alat penggulung terbuat dari tabung bambu yang dipotong- } \\
\text { potong sepanjang } 12-15 \mathrm{~cm} \text { dengan diameter antara } 8-11 \\
\mathrm{~cm} \text {. Tali pancing adalah senar nomor } 2 \text { dan mata pancing } \\
\text { terbuat dari kawat baja. Pancing gulung juga dilengkapi } \\
\text { dengan pemberat terbuat dari timah. }\end{array}$ & $\begin{array}{l}\text { Pasif, umpan, } \\
\text { selektif, dan tepi } \\
\text { sungai. }\end{array}$ \\
\hline 2. & Rawai & $\begin{array}{l}\text { Alat tangkap rawai terdiri atas tali nylon mulifilamen (tali ris) } \\
\text { dengan panjang } \pm 525 \mathrm{~m} \text { dan berukuran } 3 \mathrm{ml} \text {. Pada bagian } \\
\text { tali diikatkan senar yang sudah di terpasang mata pancing } \\
\text { dengan jarak } \pm 2 \mathrm{~m} \text {. Pada bagian ujung tali di beri pemberat } \pm \\
2 \mathrm{~kg} \text { yang terbuat dari timah ke arah dasar dan juga di beri } \\
\text { pelampung ke arah permukaan sebagai tanda ujung dari } \\
\text { rawai. Banyaknya mata pancing yang terpasang berkisar } \\
\text { antara } 100-150 \text { buah. }\end{array}$ & $\begin{array}{l}\text { Pasif, umpan, } \\
\text { selektif, mata } \\
\text { pancing banyak, } \\
\text { butuh daerah luas, } \\
\text { di tepi, dan di } \\
\text { tengah sungai. }\end{array}$ \\
\hline 3. & $\begin{array}{l}\text { Jaring tangsi } \\
\text { hanyut }\end{array}$ & $\begin{array}{l}\text { Berbentuk empat persegi panjang, mempunyai mata jaring } \\
\text { yang sama ukuran pada seluruh bagian jaring, lebar jaring } \\
\text { lebih pendek jika dibandingkan panjang, serta jumlah mesh } \\
\text { depth lebih sedikit jika dibandingkan dengan jumlah mesh } \\
\text { pada arah panjang jaring. Jaring terbuat dari senar atau } \\
\text { nylon ukuran nomor } 3 \text { dan diameter mesh } 4-6 \mathrm{~cm} \text {. Dengan } \\
\text { panjang } 100-500 \mathrm{~m} \text {, tinggi } 2-5 \mathrm{~m} \text {. }\end{array}$ & $\begin{array}{l}\text { Pasif, selektif, butuh } \\
\text { daerah luas, dan } \\
\text { tempat pemasangan } \\
\text { di tengah sungai. }\end{array}$ \\
\hline 4. & $\begin{array}{l}\text { Jaring kantong } \\
\text { hanyut }\end{array}$ & $\begin{array}{l}\text { Berbentuk empat persegi panjang, lebar jaring lebih pendek } \\
\text { jika dibandingkan panjang, serta jumlah mesh depth lebih } \\
\text { sedikit jika dibandingkan dengan jumlah mesh pada arah } \\
\text { panjang jaring. Jaring kantong terdiri atas tiga lapisan lapisan } \\
\text { luar kiri dan kanan mempunyai diameter mesh yang sama } \\
\text { yaitu } 4-6 \mathrm{~cm} \text {. Dan pada bagian tengah mempunyai ukuran } \\
\text { mesh } 1,25 \mathrm{~cm} \text {. Tinggi } 2-3 \mathrm{~m} \text {. Panjang } 100-500 \mathrm{~m} \text {. }\end{array}$ & $\begin{array}{l}\text { Pasif, selektif, butuh } \\
\text { daerah luas, dan } \\
\text { tempat pemasangan } \\
\text { di tengah sungai. }\end{array}$ \\
\hline 5. & Jaring cawang & $\begin{array}{l}\text { Anyaman terbuat dari tali nylon. Berbentuk sama seperti } \\
\text { jaring tangsi, tetapi ukuran meshnya jauh lebih lebih besar } \\
\text { dibandingkan jaring tangsi yang berukuran } 11 \mathrm{~cm} \text {. Panjang } \\
2.000 \mathrm{~m} \text { dan tinggi } 4 \mathrm{~m} \text {. Jaring ini di rancang untuk } \\
\text { menangkap ikan-ikan besar, terutama ikan cawang. }\end{array}$ & $\begin{array}{l}\text { Pasif, selektif, butuh } \\
\text { daerah luas, dan } \\
\text { tempat pemasangan } \\
\text { di tengah sungai. }\end{array}$ \\
\hline 6. & Belad & $\begin{array}{l}\text { Berbentuk empat persegi panjang, mempunyai mata jaring } \\
\text { yang sama ukuran pada seluruh bagian jaring, lebar jaring } \\
\text { lebih pendek jika dibandingkan panjang, serta jumlah mesh } \\
\text { depth lebih sedikit jika dibandingkan dengan jumlah mesh } \\
\text { pada arah panjang jaring. Jaring terbuat dari nylon dan } \\
\text { diameter mesh } 0,25 \mathrm{~cm} \text {, dengan panjang } 100 \mathrm{~m} \text {, tinggi } \\
\text { kurang lebih } 6 \mathrm{~m} \text {. }\end{array}$ & $\begin{array}{l}\text { Pasif, perangkap, } \\
\text { tidak selektif, dan } \\
\text { daerah yang luas. }\end{array}$ \\
\hline
\end{tabular}

Sumber/Sources: Gaffar et al. (2006) 